\title{
Cities and Calamities: Learning from Post-Disaster Response in Indonesia
}

\author{
Josef Leitmann
}

\begin{abstract}
The article examines the post-disaster response to recent urban-centered calamities in Indonesia, extracting lessons learned and identifying specific implications for public health. Brief background information is provided on the December 2004 tsunami and earthquakes in Aceh and Nias and the May 2006 earthquake in Yogyakarta and Central Java provinces. Another brief section summarizes the post-disaster response to both events, covering relief and recovery efforts. Lessons that have been learned from the post-disaster response are summarized, including: (a) lessons that apply primarily to the relief phase; (b) lessons for rehabilitation and reconstruction; (c) do's and don'ts; (d) cityspecific observations. Finally, several implications for urban public health are drawn from the experiences to address health inequities in the aftermath of disasters. An initial implication is the importance of undertaking a serious assessment of health sector damages and needs shortly following the disaster. Then, there is a need to distinguish between different types of interventions and concerns during the humanitarian (relief) and recovery phases. As recovery proceeds, it is important to incorporate disaster preparation and prevention into the overall reconstruction effort. Lastly, both relief and recovery efforts must pay special attention to the needs of vulnerable groups. In conclusion, these lessons are likely to be increasingly relevant as the risk of urban-centered disasters increases.
\end{abstract}

KEYWORDS Disaster, Indonesia, Public health, Urban

\section{BACKGROUND}

Indonesia has recently been struck by a series of major disasters that have largely affected cities: the 2004 tsunami and earthquakes (devastating the cities of Banda Aceh and Meulaboh) and the 2006 central Java earthquake (impacting the city and suburbs of Yogyakarta) with an ensuing tsunami (hitting the southwest Java resort town of Pangandaran). Background is provided in this section on the impact of these calamities and the post-disaster response in each case.

\section{Recent Calamities in Indonesia}

Tsunami and Earthquakes in Aceh and Nias On December 26, 2004, a massive earthquake registering 9.0 on the Richter scale struck $150 \mathrm{~km}$ off the coast of Aceh province. This triggered a tsunami that hit Aceh 45 min later and devastated an $800-\mathrm{km}$ coastal strip. Three months later, another powerful earthquake hit the islands of Nias and Simeulue. Roughly 130,000 people died in these events with another 37,000 missing and presumed dead. ${ }^{1}$ The disasters left over 500,000 people homeless, with more than 100,000 homes in need of rebuilding. Damages and 
losses were calculated at US\$4.5 billion, with the most affected sectors being housing, agriculture and fisheries, infrastructure, and the environment. ${ }^{2}$ Much of the impact was in the cities of Banda Aceh (one-quarter of the city's 400,000 people were killed) and Meulaboh (30,000 of the population of 120,000 were lost).

Earthquake in Yogyakarta and Central Java On May 27, 2006, an earthquake measuring 6.3 on the Richter scale struck Java island about $33 \mathrm{~km}$ south of Bantul district in the highly urbanized Yogyakarta Province. ${ }^{19}$ The tremors lasted for $52 \mathrm{~s}$, and hundreds of aftershocks followed. Striking in the early morning hours, the earthquake trapped many people in their homes, which subsequently collapsed. The disaster took over 5,700 lives (4,659 in Yogyakarta Province and 1,057 in Central Java province) with injury estimates ranging from 37,000-50,000. The total amount of damages and losses was initially estimated at US\$3.1 billion, i.e., much higher than those caused by the tsunami in Sri Lanka, India, and Thailand, and similar in scale to the earthquakes in Gujarat (2001) and Pakistan (2005). Much of the damage was done to dwellings $(300,000+$ need to be rebuilt) and private sector buildings with relatively less damage to infrastructure than in Aceh and Nias. ${ }^{3}$

\section{Post-Disaster Response}

Aceh and Nias During a 3-month period ending on March 31, 2005, relief operations proceeded and achieved several important milestones:

- unprecedented generosity in the form of pledges, material and human resources;

- schools reopened more-or-less on-time, albeit in often temporary facilities;

- there was no outbreak of infectious diseases ${ }^{4}$;

- food was distributed to virtually all affected areas;

- hundreds of thousands of tons of tsunami debris were cleared;

- temporary shelters (tents and barracks) were made available to those who could not be housed with friends and relatives;

- cash-for-work programs were initiated to provide families with an income.

At the same time, several recovery-related events were underway: (a) Bappenas initiated and concluded a participatory process to develop a master plan for rehabilitation and reconstruction; (b) the government decided to create a special ministerial-level agency to coordinate the reconstruction (the Badan Rehabilitasi dan Rekonstruksi or BRR); and (c) donors consolidated their pledges for the reconstruction, including creation of a $\$ 550$ million multi-donor trust fund. ${ }^{20}$

During the recovery, impressive physical progress has taken place despite unfavorable conditions. For example, nearly 42,000 houses have been built or are under construction, 524 schools have been constructed with 2,430 new teachers, 113 health facilities have been restored, $490 \mathrm{~km}$ of roads have been restored, the agriculture sector has been largely revived, and 148,000 micro-credit loans have been made. ${ }^{5}$ This was achieved in a province that suffered from 30 years of civil strife, with a pre-tsunami reputation for corruption where, after the disaster, local government was devastated, transport and logistics are a continuing challenge, and pressure for autonomy (including the application of shariah law) makes for complicated local politics. Still, the needs are immense: nearly 80,000 houses still need to be built along with 1,500 additional schools and 2,500 km of roads. The economy is still artificially driven by the reconstruction, inflation in 2006 is much higher than the national average at $23 \%$ (down from over $40 \%$ in 2005 ), low 
incomes make Aceh the second poorest province in Indonesia, and areas like Nias island continue to be underserved by the recovery.

Yogyakarta and Central/SW Java The response to the 2006 earthquake and tsunami differed, partly given the smaller scale of the disaster. Government agencies and civil society organizations reacted more quickly to provide relief, partly because the affected areas were much more accessible and partly because effective local governments were able to respond. Domestic health staff from around the country were mobilized overnight to provide emergency relief, while field hospitals and orthopedic help were provided quickly by international assistance. A damage and loss assessment was pulled together in the 2 weeks following the earthquake by Bappenas and the international community. The earthquake eerily also took place shortly before the follow-up government-donor coordination meeting where the focus was on reconstruction. At the meeting, Bappenas and local governments committed to prepare an action plan for recovery. For the tsunami, no in-depth damage and loss assessment was conducted and no action plan is being developed. Instead, opportunities are being sought to link reconstruction efforts, given the physical proximity of the disaster-affected areas.

The relief effort proved generally effective, with widespread medical care and limited disease outbreaks (tetanus was not properly controlled), provision of temporary shelters, distribution of food, reopening of schools, etc. The latest figures indicate that 250,000 emergency shelter kits have been distributed and 27,000 tons of food and nonfood items have been delivered. ${ }^{6}$ Promises of compensation were made by both the Yogyakarta and Central Java provincial governments, although in different amounts and schemes, but neither fully materialized. Homeowners have not waited in many cases and are rebuilding using recycled debris. On the official side, an initial 3,000 homes are under construction through the World Bank's community-driven Urban Poverty Project, and several donors are supporting largescale provision of low-cost core shelter.

\section{GENERAL LESSONS LEARNED}

These calamities with a high urban impact provide a wealth of information and experience from which lessons can be culled to improve how we respond to future disasters. This section summarizes two sets of lessons: those learned from the relief phase and those that have emerged from the longer period of rehabilitation and reconstruction. The section concludes with a simple set of do's and don'ts as guidance for the future and urban-oriented lessons.

\section{Lessons from the Relief Phase}

The World Health Organization (WHO) recently conducted a regional forum (Health Action in Crises) that generated a useful set of lessons learned from the relief phase of recent disasters in the Indian Ocean area and which have broader applicability beyond the health sector. These are summarized in Table 1 below.

\section{Lessons from the Recovery Phase}

Lesson: Clear designation of a coordinating mechanism facilitates both relief and recovery. At the same time, space should be made for informal mechanisms. Both 
TABLE 1 Lessons learned from recent crises $^{7}$

\begin{tabular}{ll}
\hline Area & Lesson \\
\hline Preparedness & Preparedness and national capacity \\
& building for risk management and \\
& vulnerability essential \\
Immediate availability of up-to-date and \\
credible information essential for \\
assessing, monitoring, and taking \\
actions in emergencies \\
Positive experience, but future \\
implementation requires additional \\
efforts in management, planning, \\
and institutional capacity building \\
Improvement of response needed \\
in mass casualty management, \\
water and sanitation, nutrition, \\
noncommunicable diseases, maternal \\
and newborn health, mental health \\
Private sector and military frequently \\
involved; need to agree on procedures/ \\
criteria for collaboration, and joint efforts \\
Gaps in joint work in nutritional \\
assessments and medical aspects of \\
management of nutrition; need to \\
strengthen coordination between \\
the health, water and sanitation, \\
and nutrition clusters \\
Vulnerability of children and pregnant \\
women need to be addressed; \\
need for data disaggregated by sex; \\
need to assess impact of response \\
on women and field female workers; \\
adequate supplies in reproductive \\
health and emergency obstetrics \\
Local experts trained to international \\
standards will form a valuable resource for \\
their region, providing long-term support \\
Identification and mobilization of \\
appropriately equipped and trained \\
personnel quickly is essential; important \\
to have a roster of experts on call \\
\hline
\end{tabular}

should operate at three levels: within government, within the international community, and between government and the international community.

Lesson: Outlining roles, responsibilities, outcomes, and time frames in moving from relief to recovery can help to better focus post-disaster response resources. Specific tools like a clear damage and loss assessment and a straightforward recovery strategy can assist this process. ${ }^{17}$

Lesson: Attention to good governance is a fundamental building block of any post-disaster response. Integrating public participation, transparency, and account- 
ability into both the relief and recovery phases pays off in terms of better planning, improved implementation, and reduced corruption.

Lesson: Relief and recovery efforts will be more effective if they identify, use, and strengthen existing social capital (community-based skills, programs, and networks). The community-driven approach to post-disaster recovery, which builds on this social capital, requires significant investments of time and human resources but has results in greater client satisfaction, more rapid disbursement, and local empowerment.

\section{Do's and Don'ts}

A recent self-assessment exercise by the Multi-Donor Fund for Aceh and Nias ${ }^{8}$ has generated a set of lessons, summarized in Table 2, which can be readily turned into a short list of do's and don'ts for post-disaster response.

\section{Lessons for Cities}

As urban areas were particularly hard-hit in the Indonesian disasters, it is possible to translate some of the general lessons listed above into city-specific observations. Some preliminary guidance would include:

- During the relief phase, municipal authorities can take the lead in specialized activities such as treating serious casualties or debris management because they are especially equipped to do so (in these cases, with hospitals and waste management services).

- To do so, municipal departments and services need to heighten their awareness of disaster risks and the ability to coordinate their responses.

- The partial destruction of urban neighborhoods and infrastructure can be an opportunity to build back better with improved designs, facilities, and services

- Enforcing building codes and ensuring that earthquake-resistant construction techniques are used in the recovery process are important mitigating measures against future disasters.

TABLE 2 Summary of post-disaster do's and don'ts

\begin{tabular}{|c|c|}
\hline Do & Don't \\
\hline $\begin{array}{l}\text { Be realistic about the timing and } \\
\text { approach to rebuilding homes, } \\
\text { considering the need for emergency, } \\
\text { transitional and permanent shelter }\end{array}$ & $\begin{array}{l}\text { Construct only shelters; instead, } \\
\text { build settlements with } \\
\text { infrastructure and land tenure } \\
\text { through a participatory planning } \\
\text { process }\end{array}$ \\
\hline $\begin{array}{l}\text { Pick the right partners and delivery mechanisms } \\
\text { to maximize the speed and effectiveness of investments }\end{array}$ & $\begin{array}{l}\text { Neglect logistics and transportation } \\
\text { needs that can create real } \\
\text { bottlenecks that will slow down } \\
\text { both relief and recovery efforts }\end{array}$ \\
\hline $\begin{array}{l}\text { Pay attention to environmental consequences } \\
\text { in the relief and recovery phases to avoid } \\
\text { costly mistakes later on }\end{array}$ & $\begin{array}{l}\text { Downplay the importance of } \\
\text { monitoring, evaluation, } \\
\text { and quality control which are } \\
\text { critical for managing the } \\
\text { post-disaster response }\end{array}$ \\
\hline
\end{tabular}


- More generally, disaster mitigation and management should be elements of urban planning (master plans, spatial planning, city development strategies, etc.)

- Cities may receive a disproportionate share of recovery resources simply because they may be more accessible and better-equipped than remoter rural areas.

\section{ADDRESSING HEALTH INEQUITIES IN THE AFTERMATH}

These more general lessons can now be brought down to the level of how public health is delivered following a disaster in a more equitable manner. The analysis here relies less on specific examples from the Indonesian context and more from decades of global experience by WHO and others. Four areas are emphasized in this article: (a) assessing health sector damages and needs; (b) clearly differentiating the roles of public health in the humanitarian and recovery phases; (c) incorporating disaster prevention and preparedness in the recovery; and (d) addressing the needs of vulnerable groups.

\section{Assessing Health Sector Damages and Needs}

Properly assessing the impact of a disaster on human health and the health care system is fundamental to:

- establish health care priorities,

- follow trends and reassess priorities,

- detect and respond to epidemics,

- evaluate program effectiveness,

- ensure targeting of resources,

- assess the quality of health care. ${ }^{9}$

During the relief phase, there is a need to gather basic loss data (number of dead and injured), assess the threats to human health (especially epidemics), determine what measures and investments need to be taken to respond to immediate threats, and provide emergency care. Moving to the recovery phase, the damage assessment needs to be converted into a concerted program to revive the health sector and system so that they can increasingly deliver needed services to reduce morbidity and mortality. There is also a need for post-disaster epidemiologic studies to understand and address changes in disease transmission, and posttraumatic stress disorder/mental health.

\section{Differing Roles in the Relief and Recovery Phases}

The focus of the public health effort will differ between the emergency and reconstruction phases of post-disaster response. For example, during the emergency response, environmental health efforts would concentrate on disease surveillance, water quality, safe food, sanitation, waste management, and related guidelines for relief work. During rehabilitation and reconstruction, the emphasis would be on developing an environmental health strategy, encouraging healthier settlements, strengthening emergency response systems, and building preparedness. ${ }^{10}$

More specifically, during the relief phase, the Centers for Disease Control have identified a set of myths to be avoided and realities to recognize in the health response. These are summarized in Table 3 below. 
TABLE 3 Myths and realities in the public health response to disasters ${ }^{9,11}$

\begin{tabular}{|c|c|}
\hline Myth & Realities \\
\hline \multirow[t]{3}{*}{$\begin{array}{l}\text { External medical volunteers with any } \\
\text { kind of medical background are needed }\end{array}$} & $\begin{array}{l}\text { The local population almost always covers } \\
\text { immediate lifesaving needs }\end{array}$ \\
\hline & $\begin{array}{l}\text { Only skills that are not available in the affected } \\
\text { country may be needed }\end{array}$ \\
\hline & Few survivors owe their lives to outside teams \\
\hline \multirow[t]{3}{*}{$\begin{array}{l}\text { Any kind of assistance is needed, } \\
\text { and it's needed now! }\end{array}$} & $\begin{array}{l}\text { A hasty response not based on impartial } \\
\text { evaluation can be counterproductive }\end{array}$ \\
\hline & $\begin{array}{l}\text { Unrequested goods are inappropriate, burdensome, } \\
\text { divert scarce resources, and more often burned } \\
\text { than separated and inventoried }\end{array}$ \\
\hline & $\begin{array}{l}\text { Seldom-needed items include used clothing, over- } \\
\text { the-counter, and prescription drugs, blood } \\
\text { products, medical teams, and field hospitals }\end{array}$ \\
\hline \multirow{3}{*}{$\begin{array}{l}\text { Epidemics and plagues are } \\
\text { inevitable after every disaster }\end{array}$} & Epidemics rarely occur after a disaster \\
\hline & $\begin{array}{l}\text { Dead bodies will not lead to catastrophic } \\
\text { outbreaks of exotic diseases }\end{array}$ \\
\hline & $\begin{array}{l}\text { Proper resumption of public health services } \\
\text { will ensure safety (immunizations, sanitation, } \\
\text { waste disposal, water quality, and food safety) }\end{array}$ \\
\hline \multirow[t]{2}{*}{$\begin{array}{l}\text { The community is too shocked } \\
\text { and helpless to contribute }\end{array}$} & $\begin{array}{l}\text { Dedication to the common good is the most } \\
\text { frequent response to natural disasters } \\
\text { across all cultures }\end{array}$ \\
\hline & $\begin{array}{l}\text { Most rescue, first aid, and transport is from other } \\
\text { casualties and bystanders }\end{array}$ \\
\hline
\end{tabular}

For the recovery phase, WHO has identified the key elements of rebuilding a disrupted health sector following a disaster. In most cases, this requires:

- equity-the expansion of service provision to underserved areas and populations (this can integrate formerly divided health care services);

- effectiveness-increasing the access to and quality of key services such as surgical basic care, laboratory, and other diagnostic services and in-patient care;

- appropriateness-adoption of new service delivery models to respond to new health needs, a changed environment, or if the previous system was outdated;

- efficiency_-greater overall efficiency with savings used to finance some of these measures. $^{18}$

\section{Incorporating Disaster Prevention and Preparedness}

It is generally agreed that there are three elements for effective disaster prevention and preparedness: (a) an accurate analysis of hazards and vulnerable populations; (b) formulation of disaster preparedness and response plans; and (c) communicating prevention and preparedness to the public and key decision-makers. ${ }^{12}$ More generally, these elements are embodied in the Hyogo Framework for Action that resulted from the 2005 World Conference on Disaster Reduction. Operationally, they have been converted into a set of measurable benchmarks by WHO, both as 
guidance and to enable evaluation of a country or a subnational area's performance in this area (see Box 1).

BOX 1: WHO benchmarks for emergency preparedness and response (EPR) $)^{13}$

Legal framework, functioning coordination mechanisms, and an organizational structure in place for health EPR at all levels involving key stakeholders

Regularly updated disaster preparedness and emergency management plan for health sector and SOPs (emergency directory, national coordination focal point) in place

Emergency financial (including national budget), physical and human resource allocation and accountability procedures established

Rules of engagement (including conduct) for external humanitarian agencies based on needs established

Community plan for mitigation, preparedness and response developed, based on risk identification and participatory vulnerability assessment and backed by higher level capacity

Local capacity for emergency provision of essential services and supplies (shelters, safe drinking water, food, communication)

Advocacy and awareness developed through education, information management, and communication (pre-, during, and post-event)

Capacity to identify risks and assess vulnerability at all levels established

Human resources capabilities continuously updated and maintained

Health facilities built/modified to withstand expected risks

Early warning and surveillance systems for identifying health concerns established

\section{Addressing the Needs of Vulnerable Groups}

The composition and needs of vulnerable populations will differ according to the location and nature of each disaster. Typically, though, vulnerable groups include: the poor, women, children, the elderly, the handicapped, and people with preexisting mental disorders. ${ }^{14}$ These groups may suffer disproportionately during a disaster, may need specialized medical attention during the relief phase, and could have specific concerns during the recovery such as their ability to access appropriate health care services.

Disasters can also create a new class of vulnerable group-people with psychiatric disorders due to trauma, from the disaster, which often manifests only 1 to 3 months following the event. The magnitude of this vulnerability can be quite sizeable. For example, it is estimated that between 400,000 and 600,000 adults throughout Honduras were emotionally affected by the Hurricane Mitch disaster. Posttraumatic stress syndrome and depressive disorder are the two most common reactions that affect survivors. For the countries hit by the 2004 tsunami, WHO estimates that $20-40 \%$ of the affected population suffered mild psychological distress, $30-50 \%$ exhibited moderate or severe distress, and $10-15 \%$ had mental disorders. $^{15}$ 
These afflictions can be treated by standard medical procedures (counseling, psychiatric treatment, psychotropic drugs, etc.) but also by rebuilding communities, livelihoods, and social interaction to give people a renewed sense of place and future. The delivery of mental health and psychosocial support services typically occurs through four levels: (a) community mental health services; (b) mental health care through primary health care; (c) care and support outside the formal health sector; and (d) self and family care. ${ }^{15}$

\section{CONCLUSION}

These lessons are increasingly relevant as the risk of disaster augments. We are likely to see more urban-centered calamities in the future due to: (a) continued urbanization; (b) increasing population density; (c) more settlement in high-risk areas; (d) increased exposure to technological and industrial hazards; (e) a higher risk of terrorist incidents; (f) emerging infectious diseases such as SARS and avian $\mathrm{flu}^{16}$; and $(\mathrm{g})$ aging populations in industrialized countries. ${ }^{9}$

\section{ON-LINE RESOURCES FOR POST-DISASTER RESPONSE}

Asia Disaster Preparedness Center (http://www.adpc.ait.ac.th)

Center for International Disaster Information (http://www.cidi.org)

Center for Reconstruction and Development (http://www.rec-dev.com)

Crisis Web (http://www.crisisweb.org)

Disaster Relief (http://www.disasterrelief.org)

Disaster Resource Network (http://www.disaster-resource.com)

Disaster Response Network (http://www.disasterresponse.net)

Inter-Action (http://www.interaction.org/disaster)

International Federation of Red Cross and Red Crescent Societies (http:// www.ifrc.org/what/dp/mitigate.asp)

Natural Hazards Center (http://www.colorado.edu/hazards)

PAHO Program on Emergency Preparedness (http://www.paho.org/english/PED)

ProVention Consortium (http://www.proventionconsortium.org)

UNDP Bureau for Crisis Prevention and Recovery (http://www.undp.org/erd/disred)

UN International Strategy for Disaster Reduction (http://www.unisdr.org)

World Bank Disaster Management Facility (http://www.worldbank.org/dmf)

\section{REFERENCES}

1. BRR (Aceh-Nias Rehabilitation and Reconstruction Agency). Aceh and Nias One Year after the Tsunami: The Recovery Effort and Way Forward. Banda Aceh, Indonesia: BRR and international partners; 2005.

2. Bappenas (National Development Planning Agency). Indonesia: Preliminary Damage and Loss Assessment-The December 26, 2004 Natural Disaster. Jakarta, Indonesia: Bappenas and international partners; 2005.

3. Government of Indonesia. Preliminary Damage and Loss Assessment: Yogyakarta and Central Java Natural Disaster. Jakarta, Indonesia: Bappenas; 2006.

4. Morgan O, Ahern M, Cairncross S. Revisiting the tsunami: Health consequences of flooding. PLoS Med. 2005;2(6):491-493.

5. BRR. Membangun Tanah Harapan (first-year report on the operations of the BRR). Banda Aceh, Indonesia: BRR; 2006. 
6. IOM (International Organization for Migration). Yogyakarta Earthquake Response. 2006;1:6.

7. WHO. Health Action in Crises Vision and Strategic Directions (Powerpoint Presentation). Geneva: WHO; 2006.

8. Multi Donor Fund for Aceh and Nias (MDF). The First Year of Rebuilding Together: Results, Challenges and Opportunities. Jakarta, Indonesia: World Bank; 2006.

9. Noji, EK. The Public Health Consequences of Disaster. Washington, DC: Centers for Disease Control \& Prevention; 2005.

10. WHO. Environmental Health Relief Efforts after the Tsunami in South East Asia. New Delhi: WHO Regional Office for South-East Asia; 2005.

11. De Goyet, C. Epidemics caused by dead bodies: a disaster myth that does not want to die. Pan Am. J. Public Health. 2006;5:297-299.

12. Hooke W, Rogers P (eds). Public Health Risks of Disasters: Communication, Infrastructure, and Preparedness. Washington, DC: National Research Council; 2005.

13. WHO. Progress on the Benchmarks for Emergency Preparedness and Response (Regional Consultation on Emergency Preparedness and Response: From Lessons to Action, Bali, 27-29 June 2006). New Delhi: WHO Regional Office for South-East Asia; 2006b.

14. Logue J. Disasters, the Environment and Public Health: Improving Our Response. Am. J. Public Health. 1996;86(9):1207-1210.

15. WHO. WHO Framework for Mental Health and Psychosocial Support after the Tsunami. New Delhi: WHO Regional Office for South-East Asia; 2005c.

16. Lipsitch M. Avian Flu: Preparing for a Pandemic. Harv. Public Health Rev. 2006; Winter.

17. Bappenas. Rencana dan Langkah-langkah Penanggulangan Paska Bencana Gempa Bumi Yogyakarta (powerpoint presentation). Yogyakarta, Indonesia; Bappenas and international partners; 2006.

18. Pavignan, E. Formulating Strategies for the Recovery of a Disrupted Health Sector. Geneva:WHO; 2006.

19. Wikipedia. July 2006 Java earthquake. http://En.wikipedia.org. Accessed August 15, 2006.

20. World Bank. Aceh Public Expenditure Analysis: Spending for Reconstruction and Poverty Reduction. Jakarta, Indonesia: World Bank; 2006. 